\title{
NEW RADIOCARBON DATES FROM THE BALKANS (DUBENE-SAROVKA): APPROACH TO THE EARLY BRONZE ABSOLUTE CHRONOLOGY IN UPPER THRACE
}

\author{
Lolita Nikolova \\ International Institute of Anthropology, PO Box 112065, Salt Lake City, Utah 84117-2065 USA, and Prehistory Foundation, \\ 30 Krivolac, Karlovo 4300, Bulgaria; Adjunct-Associate Professor at University of Utah, Salt Lake City, Utah, USA. \\ Email: Inikolova@iianthropology.org. \\ Jochen Görsdorf \\ Deutsches Archäologisches Institut, Eurasien-Abteilung, Postfach 330014, 14191 Berlin, Germany. Email: 14C@ dainst.de.
}

\begin{abstract}
This paper addresses the absolute chronology of the earlier Yunatsite and Ezero cultures in Upper Thrace (South Bulgaria), from Early Bronze I and the beginning of Early Bronze II. The two newly obtained radiocarbon dates from Early Bronze Dubene-Sarovka (the Upper Stryama Valley) are published and discussed in a detailed stratigraphic and comparative Early Bronze I-Early Bronze II context. Date Bln-5233 (3490-3120 cal BC) is the first ${ }^{14} \mathrm{C}$ date from the Upper Maritsa valley from Early Bronze I with well-defined stratigraphic context and values earlier than $3100 \mathrm{BC}$. This date adds new arguments to the discussion of the ${ }^{14} \mathrm{C}$ dates from Yunatsite 15 and Plovdiv-Nebet Tepe, and addresses the question of the comparative chronology of Yunatsite I and Ezero I cultures from the late fourth millennium BC.

The sample of the date Bln-5231 (2870-2620 cal BC) comes from a level on the border between Early Bronze I and Early Bronze II. On one hand, its values preceded the values of the earlier-obtained ${ }^{14} \mathrm{C}$ dates from IIB layer and confirmed the stratigraphic sequence at Dubene-Sarovka tell. On the other hand, the calibrated values seem to be later than the vast comparative chronology of the end of the Dubene IIA-the beginning of Dubene IIB (ca. 3000 BC). Similar problems occur with dates from Yunatsite and Ezero. The published new dates from Dubene-Sarovka are part of the project on complex elaborating of the Early Bronze absolute chronology in the Balkans, and especially on contextual analysis of the ${ }^{14} \mathrm{C}$ dates.
\end{abstract}

\section{INTRODUCTION}

Our objective here is to provide two new radiocarbon dates with their stratigraphic context from the newly investigated tell in the Upper Stryama valley-Dubene-Sarovka, to consider their interrelations, and to put them together in the newly considered EB I-II comparative chronology of Upper Thrace.

The Middle and Upper Maritsa (Upper Thrace, central south and southeast Bulgaria) and its tributaries (e.g. the Stryama) are a key region for the elaboration of the Early Bronze (EB) ${ }^{14} \mathrm{C}$ chronology of the Balkans. The archaeological sites from this region have provided a solid record foundation-long stratigraphic sequences, numerous ${ }^{14} \mathrm{C}$ dates, and contact data with close and distant cultures (Nikolova and Görsdorf 1998; Nikolova 1999a). Nevertheless, recent interpretations of the ${ }^{14} \mathrm{C}$ dates from the eastern and western parts of Upper Thrace have resulted in contradictory hypotheses about the absolute chronology of the Early Bronze cultures in the region (Ezero and Yunatsite cultures, respectively). The main reason is the difference in the ${ }^{14} \mathrm{C}$ dates from both key sites-Ezero and Yunatsite tells. Then, it has become apparent that we need to complete the EB absolute chronology of the different micro-regions in the Maritsa valley, to include them in the comparative characteristics of the mentioned popular sites in order to compile a detailed EB absolute chronology of Upper Thrace cultures.

\section{Dubene-Sarovka: Stratigraphy and Relative Chronology}

Dubene-Sarovka is a low tell in northwest Thrace at $315 \mathrm{~m}$ above sea level. It is situated on the left side of the valley of the Upper Stryama, one of the biggest tributaries of the Maritsa River (Figure 1), in the Karlovo Hollow, which is divided from the Maritsa basin by the middle ranges of the Sredna Gora Mountains. Passes of the western Sredna Gora Mountains connect the Karlovo Hollow with 


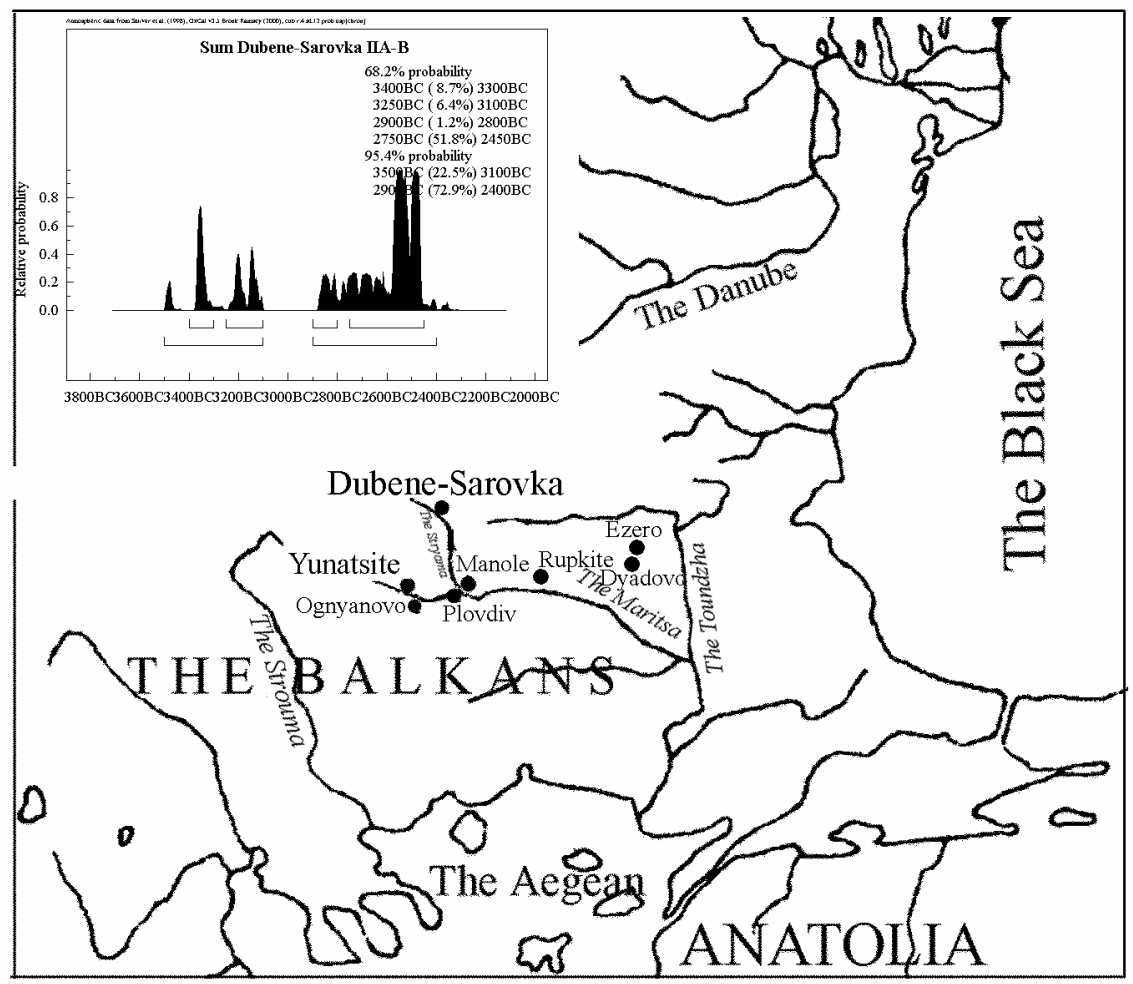

Figure 1 Map of the Balkans showing the main sites studied here. Inset: chart of the sum-probability of Dubene-Sarovka IIA-B ${ }^{14} \mathrm{C}$ dates $(\mathrm{n}=4)$.

Sofia Field in southwest Bulgaria and farther with the Morava valley in eastern Serbia, while to the east there are small interrelated hollows connecting the upper Stryama valley with the vast Upper Toudzha valley.

The systematic excavations of the Dubene-Sarovka tell began in $1992^{1}$. During eight seasons, the site was recovered over more than $4000 \mathrm{~m}^{2}$ at a depth of $0.50-1.00 \mathrm{~m}$ below the surface, while control trenches reached the subsoil at about $-2.00 \mathrm{~m}$ from the datum. As a result, thick cultural layers from Late Copper (Karanovo VI culture) and Early Bronze I-II (Yunatsite culture I-II) have been documented (Nikolova 1999b). The stratigraphic data were supplemented by a bountiful ceramic record and by archaeomagnetic (Kovacheva et al. 1995; also excavation campaign 1999) and ${ }^{14} \mathrm{C}$ samples (Nikolova and Görsdorf 1998). The complex results from these sites contributed considerably to the modern Early Bronze chronology of the Balkans (Nikolova 1999a, 1999b).

The Early Bronze levels at Dubene-Sarovka have been divided into two main stages, IIA and IIB, respectively. The surface data and some pits documented a third stage (IIC), from Early Bronze III, characterized by pointed-bottom cups and plain pottery. The levels of that stage had been destroyed during the agricultural activity over the tell area.

${ }^{1}$ Since 1992, the excavations at Dubene-Sarovka have been directed by Dr Lolita Nikolova. In 1993 and 1994 Dr Alexander Bonev was the first director who continued to participate in the following campaigns as a supervisor of the excavations. The investigations in 1999-2000 were executed thanks to the volunteer assistance of undergraduate students from the Department of Archaeology at Veliko Turnovo University (Bulgaria). 
Dubene-Sarovka IIB (EB II) is, for now, the best-excavated layer on the tell. House structures with a horizontal and vertical stratigraphic correlation have been excavated. The IIB layer is about $1 \mathrm{~m}$ thick and comprises three to six house levels preserved in different sectors of the tell. Characteristic of the IIB levels is the encrusted pottery that defines the ceramic style of most of the Early Bronze II Balkan cultures. The superimposed house levels along with ceramic data infer three phases: Dubene-Sarovka IIB1-3, which corresponds to Yunatsite 14-9, Ezero 10-4, Pernik II, Coţofeni II-III, Sitagroi Va, Kostolac, and Vučedol ${ }^{2}$, etc., dated from the Early Bronze II (Nikolova 1999b: 62-70). There are two ${ }^{14} \mathrm{C}$ dates from Dubene-Sarovka IIB (Nikolova and Görsdorf 1998):

Bln-4903 $4003 \pm 36$ BP, 2570-2470 cal BC (68.2\% confidence), 2630-2450 cal BC (95.4\% confidence) ${ }^{3}$ (Layer IIB1)

Bln-4900 $3993 \pm 36$ BP, 2565-2465 cal BC (68.2\% confidence), 2620-2400 cal BC (95.4\% confidence) (Layer IIB2)

In general, the values of the dates confirm the contemporaneous occupation of Dubene-Sarovka IIB1 and Yuntasite 14-13, and Dubene-Sarovka IIB2-Yunatsite 12-11 within the first half of the third millennium BC (see the discussion in Nikolova 1999b:64-5), although we need additional samples for a precise chronology of the levels to which they belonged.

The Dubene-Sarovka IIA layer is comprised of pottery typical of Early Bronze I in the Balkansmostly plain burnished with emblematic channels and initiated encrusted ceramics. For the time being, the thickest sector cultural layer is about $1 \mathrm{~m}$ and consists of four house levels.

The Early Bronze I layer has been initially documented by a house on the southern steep periphery of the tell, as well as by a pit near that house (P15-93). The pottery from that stage has parallels at Yunatsite 17-15, Ezero 13-11, Baden, Cernavoda, Sitagroi IV, etc., dated from Early Bronze I. In 1999, the control trench (H18-4) in the northern central part of the tell (Nikolova 1999b:43-5, Figure 1.1) documented several levels that stratigraphically and ceramically corresponded to the IIA phase, as well as to the transition from IIA to the IIB phase. The last is represented by a hearth floor structure at a depth of $1.44 \mathrm{~m}$ from the date over which a burnt level has been documented with fragments of saucer; below there was another level with a published zigzag encrusted bowl (Nikolova 1999b: Figure 2.3). One ${ }^{14} \mathrm{C}$ sample was obtained from the level at a depth of $-1.44 \mathrm{~m}$ (Bln-5231). The ceramics have analogies at Yunatsite 15-14, but the stratigraphic situation infers that the levels belonged to the end of Early Bronze I, and was contemporaneous with Yunatsite 15, respectively with the end of Pernik I, Baden, Coţofeni I, Ezero 11, and Sitagroi IV, as well as with earlier Cernavoda II and Pit Grave Culture in the Balkans. However, calibrated values of the ${ }^{14} \mathrm{C}$ date point to later chronology (see below).

In the sector under discussion, three more levels, characterized by plain and channel pottery have been recovered in depth, below being a layer with mixed and sparsely distributed Karanovo VI and Yunatsite I sherds. The second new ${ }^{14} \mathrm{C}$ sample from Dubene-Sarovka (Bln-5233) was obtained from the last layer. Hence, the sample has very clear stratigraphic characteristics-below the lowest floor from Early Bronze I in the excavated area. The absence of ${ }^{14} \mathrm{C}$ dates from Yunatsite 16-17, as well as the calibrated values of that ${ }^{14} \mathrm{C}$ date (see below) considerably increases the recent results from Dubene-Sarovka excavations.

\footnotetext{
${ }^{2}$ See the radiocarbon dates for these cultures in Nikolova 1999a: Table A, Srdoć D et al. 1987; Srdoć D et al. 1989.

${ }^{3} \mathrm{Cp}$. the calibrated values with 3.0 version of Oxcal in Nikolova 1999b: Table A (2850-2450 cal BC). In the context of the comparative chronology, the end of IIB1 phase at Dubene-Sarovka to which the sample belongs, is ca. 2850-2800 cal BC.
} 


\section{The New Radiocarbon Dates}

Chemical pretreatment of the samples was completed through AAA treatment (Mook and Streurman 1983). The dating was performed with gas proportional counters of the Houtermans-Oeschger type using methane at $133.3 \mathrm{kPa}$ pressure as filling gas. Measurement control and data processing was executed using computers (Görsdorf 1990). Modern electronics have been used in such a way that the preamplifier, pulse amplifier, comparator, pulse shape and anti-coincidence units were located in a box $(19 \mathrm{~cm} \times 10 \mathrm{~cm} \times 5 \mathrm{~cm})$ directly connected to the counter. To reach measurement accuracy, detection of the variations of environmental radiation and the inspection of the long-term stability of the electronics was necessary (Görsdorf 2000).

The $\delta^{13} \mathrm{C}$ determinations have been studied at the Leibniz-Labor at the University of Kiel, Germany and reported in permil relative to PDB-standard. Using the measured $\delta^{13} \mathrm{C}$ values, the datings are correct for isotopic fractionation, while the ${ }^{14} \mathrm{C}$ ages are calibrated by the OxCal program, version 3.5 (Ramsey 1995, 1998, 2000) and employing the decadal calibration curve (Stuiver et al. 1998) as a first approximation for all samples. The calibration intervals are represented with a confidence of $68.2 \%$ and are rounded off to 10 years. Table 1 shows the dating results together with locations. The relatively large calibration intervals of both dates are due to the wiggle shape of the calibration curve.

Table 1 Radiocarbon dates from Dubene-Sarovka (Upper Thrace) and their calibrated individual distribution (68.2\% probability)

\begin{tabular}{|c|c|c|c|c|c|}
\hline $\begin{array}{l}\text { Lab nr } \\
\text { Sample }\end{array}$ & $\begin{array}{l}\text { Dubene-Sarovka site } \\
\text { (Stratigraphic data) }\end{array}$ & $\begin{array}{c}\delta^{13} \mathrm{C} \\
(\mathrm{PDB} \% o)\end{array}$ & ${ }^{14} \mathrm{C}$ age & $\begin{array}{l}\text { Calibrated age ranges } \\
\text { (68.2\% probability) }\end{array}$ & $\begin{array}{l}\text { Calibrated age ranges } \\
\text { (95.4\% probability) }\end{array}$ \\
\hline $\begin{array}{l}\text { Bln-5233 } \\
\text { Charcoal }\end{array}$ & $\begin{array}{l}\text { H18-4 } \\
\text { Depth: }-1.90-2.46 \mathrm{~m} \\
(+313.10 / 312.54 \mathrm{~m})\end{array}$ & $-26.8 \%$ & $4571 \pm 32 \mathrm{BP}$ & $\begin{array}{l}3490 \mathrm{BC}(1.4 \%) 3470 \mathrm{BC} \\
3370 \mathrm{BC}(35.0 \%) 3330 \mathrm{BC} \\
3220 \mathrm{BC}(14.2 \%) 3180 \mathrm{BC} \\
3160 \mathrm{BC}(17.5 \%) 3120 \mathrm{BC}\end{array}$ & $\begin{array}{l}3500 \mathrm{BC}(8.0 \%) 3460 \mathrm{BC} \\
3380 \mathrm{BC}(40.7 \%) 3300 \mathrm{BC} \\
3240 \mathrm{BC}(46.7 \%) 3100 \mathrm{BC}\end{array}$ \\
\hline $\begin{array}{l}\text { Bln-5231 } \\
\text { Charcoal }\end{array}$ & $\begin{array}{l}\text { Sq. H18-4 } \\
\text { Depth: }-1.44 \mathrm{~m} \\
(+313.56 \mathrm{~m})\end{array}$ & $-26.2 \%$ & $4145 \pm 29 \mathrm{BP}$ & $\begin{array}{l}2870 \mathrm{BC}(13.4 \%) 2830 \mathrm{BC} \\
2820 \mathrm{BC}(4.5 \%) 2800 \mathrm{BC} \\
2780 \mathrm{BC}(1.0 \%) 2770 \mathrm{BC} \\
2760 \mathrm{BC}(39.8 \%) 2660 \mathrm{BC} \\
2650 \mathrm{BC}(9.5 \%) 2620 \mathrm{BC}\end{array}$ & $\begin{array}{l}2880 \mathrm{BC}(93.7 \%) 2620 \mathrm{BC} \\
2610 \mathrm{BC}(1.7 \%) 2590 \mathrm{BC}\end{array}$ \\
\hline $\begin{array}{l}\text { Bln-4903 } \\
\text { Charcoal }\end{array}$ & $\begin{array}{l}\text { Sq. K12 } \\
\text { Depth: }-1.39 \\
(+313.61)\end{array}$ & $-24.95 \%$ & $4003 \pm 36 \mathrm{BP}$ & $\begin{array}{l}2570 \mathrm{BC}(44.0 \%) 2515 \mathrm{BC} \\
2500 \mathrm{BC}(24.2 \%) 2470 \mathrm{BC}\end{array}$ & $2630 \mathrm{BC}(95.4 \%) 2450 \mathrm{BC}$ \\
\hline $\begin{array}{l}\text { Bln-4900 } \\
\text { Grain }\end{array}$ & $\begin{array}{l}\text { Sq. F16 } \\
\text { Depth: }-1.10 \mathrm{~m} \\
(+313.90 \mathrm{~m})\end{array}$ & $-24.52 \%$ & $3993 \pm 36 \mathrm{BP}$ & $\begin{array}{l}2565 \mathrm{BC}(40.8 \%) 2520 \mathrm{BC} \\
2500 \mathrm{BC}(27.4 \%) 2465 \mathrm{BC}\end{array}$ & $\begin{array}{l}2620 \mathrm{BC}(94.0 \%) 2450 \mathrm{BC} \\
2420 \mathrm{BC}(1.4 \%) 2400 \mathrm{BC}\end{array}$ \\
\hline
\end{tabular}

\section{DISCUSSION AND CONCLUSIONS}

The long stratigraphy of Dubene-Sarovka, the numerous contact data in the context of rich and wellstratified archaeological material, the vast excavated area, and the interacted method of recording including archaeological and natural sciences all contribute to the elaboration of an accurate and complete chronology of the region. This gives reason for the ${ }^{14} \mathrm{C}$ dates to have a high recording value even though for the time being there is sole such evidence from the different levels.

Conclusions based on new stratigraphic and ${ }^{14} \mathrm{C}$ data from Dubene-Sarovka concern two periods in the Balkans-Early Bronze I, as well as the beginning of Early Bronze II. For these periods in Upper Thrace, there are ${ }^{14} \mathrm{C}$ dates from Dubene-Sarovka, Yunatsite, Plovdiv-Nebet Tepe, and possibly Manole (Yunatsite culture), and from Rupkite-Kaleto, Ezero, and Dyadovo tell (Ezero culture) 
Table 2 Radiocarbon dates from Early Bronze I and earlier Early Bronze II in Upper Thrace ${ }^{\mathrm{a}}$

\begin{tabular}{|c|c|c|c|c|}
\hline Site & Lab nr & $\begin{array}{l}\text { Sample } \\
\text { type }\end{array}$ & $\begin{array}{l}{ }^{14} \mathrm{C} \text { age } \\
(\mathrm{BP})\end{array}$ & $\begin{array}{l}\text { Comments (see calibrated val- } \\
\text { ues in Figure 2) }\end{array}$ \\
\hline \multicolumn{5}{|c|}{ Yunatsite Culture (Western Upper Thrace) } \\
\hline Dubene-Sarovka IIA & Bln-5233 & Charcoal & $4571 \pm 32$ & $\begin{array}{l}\text { EB I. From a cultural level } \\
\text { with a few EB I and Late Cop- } \\
\text { per (Karanovo VI culture) } \\
\text { sherds. }\end{array}$ \\
\hline Dubene-Sarovka IIA/B & Bln-5231 & Charcoal & $4145 \pm 29$ & $\begin{array}{l}\text { End of EB I, or beginning of } \\
\text { EB II according to the cali- } \\
\text { brated values. Hearth. }\end{array}$ \\
\hline Yunatsite 15 & Bln-3675 & Grain \& seed & $4280 \pm 60$ & $\begin{array}{l}\text { End of EB I. The only date } \\
\text { from the level that corre- } \\
\text { sponds to the comparative } \\
\text { chronology. }\end{array}$ \\
\hline Yunatsite 15 & Bln-3677 & Grain \& seed & $4080 \pm 70$ & \multirow[t]{3}{*}{$\begin{array}{l}\text { End of EB I. The calibrated } \\
\text { values correspond to EB II. }\end{array}$} \\
\hline Yunatsite 15 & $\mathrm{~B} \ln -3678$ & Grain \& seed & $4050 \pm 50$ & \\
\hline Yunatsite 15 & Bln-3676 & Grain \& seed & $4030 \pm 70$ & \\
\hline Plovdiv-Nebet Tepe "10" & Bln-4353 & Charcoal & $4610 \pm 80$ & $\begin{array}{l}\text { The steep character of the ter- } \\
\text { rain might have resulted in im- } \\
\text { precise stratigraphy; the } \\
\text { pottery from the site (unpub- } \\
\text { lished) comprises typical EB I } \\
\text { shapes and ornamentation. }\end{array}$ \\
\hline Plovdiv-Nebet Tepe 11 & Bln-4355 & Charcoal & $4280 \pm 55$ & $\begin{array}{l}\text { The date corresponds to the } \\
\text { end of EB I - EB II. But see } \\
\text { the next note. }\end{array}$ \\
\hline Plovdiv-Nebet Tepe 11 & $B \ln -4330$ & Charcoal & $4070 \pm 40$ & $\begin{array}{l}\text { Later EB II, cp. above and the } \\
\text { note on the stratigraphic prob- } \\
\text { lems of the site. }\end{array}$ \\
\hline Manole-Razkopanitsa 4 & Bln-813 & Grain \& seed & $4350 \pm 100$ & $\begin{array}{l}\text { According to the diagnostic } \\
\text { published pottery, the tell is } \\
\text { from EB III and later periods; } \\
\text { the published stratigraphy is } \\
\text { not precise and the material is } \\
\text { not completely published; } \\
\text { among the published finds is a } \\
\text { figurine that can be dated from } \\
\text { EB I. }\end{array}$ \\
\hline \multicolumn{5}{|c|}{ Ezero Culture (Eastern Upper Thrace) } \\
\hline Rupkite-Kaleto & Bln-3429 & Charcoal & $4790 \pm 60$ & $\begin{array}{l}\text { Both dates are from ditches; } \\
\text { among the preliminary pub- } \\
\text { lished material there is typical } \\
\text { of EB I pottery. }\end{array}$ \\
\hline Rupkite-Kaleto & Bln-3773 & Charcoal & $4250 \pm 150$ & \\
\hline
\end{tabular}


Table 2 Radiocarbon dates from Early Bronze I and earlier Early Bronze II in Upper Thrace ${ }^{\mathrm{a}}$ (Cont'd.)

\begin{tabular}{|c|c|c|c|c|}
\hline Site & Lab nr & $\begin{array}{l}\text { Sample } \\
\text { type }\end{array}$ & $\begin{array}{l}{ }^{14} \mathrm{C} \text { age } \\
(\mathrm{BP})\end{array}$ & $\begin{array}{l}\text { Comments (see calibrated val- } \\
\text { ues in Figure 2) }\end{array}$ \\
\hline Ezero 13 & Bln-1840 & Charcoal & $4590 \pm 100$ & EB I. All the samples are from \\
\hline Ezero 13 & Bln-1920B & Charcoal & $4500 \pm 50$ & a depth of $3.20-3.45 \mathrm{~m}$ from \\
\hline Ezero 13 & Bln-1786 & Charcoal & $4450 \pm 85$ & the date. Some of the dates \\
\hline Ezero 13 & Bln-1843 & Charcoal & $4430 \pm 50$ & $\begin{array}{l}\text { with low values originate from } \\
\text { similar context with one of the }\end{array}$ \\
\hline Ezero 13 & Bln-1841 & Charcoal & $4420 \pm 50$ & dates that have the highest val- \\
\hline Ezero 13 & Bln-1837 & Charcoal & $4415 \pm 40$ & ues. But for instance, Bln-905 \\
\hline Ezero 13 & Bln-1920 & Charcoal & $4390 \pm 50$ & and Bln-1838 from a depth of \\
\hline Ezero 13 & Bln-1158 & Charcoal & $4363 \pm 100$ & 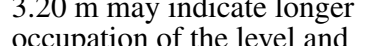 \\
\hline Ezero 13 & Bln-1838 & $\begin{array}{l}\text { Charcoal, } \\
\text { grain \& seed }\end{array}$ & $4305 \pm 65$ & $\begin{array}{l}\text { just partially overlapping of } \\
\text { the different houses. Never- }\end{array}$ \\
\hline Ezero 13 & $\mathrm{~B} \ln -1256$ & Charcoal & $4300 \pm 80$ & theless, even this interpreta- \\
\hline Ezero 13 & Bln-904 & Charcoal & $4143 \pm 100$ & tion cannot accept the values \\
\hline Ezero 13 & Bln-905 & Charcoal & $4113 \pm 100$ & after $3100 \mathrm{BC}$ which is the lat- \\
\hline Ezero 13 & Bln-1159 & Charcoal & $4099 \pm 100$ & of Ezero 13. \\
\hline Ezero 12 & Bln-1836 & Charcoal & $4160 \pm 55$ & $\begin{array}{l}\text { EB I. The calibrated values are } \\
\text { later than the comparative } \\
\text { chronology of the level. }\end{array}$ \\
\hline Ezero 12 & Bln-903 & Charcoal & $3935 \pm 100$ & \\
\hline Ezero 11 & $B \ln -902$ & Charcoal & $4360 \pm 100$ & End of EB I. \\
\hline Ezero 10 & $B \ln -727$ & Grain \& seed & $4315 \pm 100$ & Beginning of EB II. \\
\hline Ezero 10 & Bln-726 & Grain \& seed & $4285 \pm 100$ & \\
\hline Ezero 10 & Bln-1835 & Grain \& seed & $4260 \pm 45$ & \\
\hline Ezero 10 & Bln-725 & Grain \& seed & $4120 \pm 100$ & \\
\hline Dyadovo 10 & Gak-20464 & Charcoal & $4510 \pm 60$ & $\begin{array}{l}\text { EB I. Unpublished ceramics } \\
\text { from that level excavated by } \\
\text { the Bulgarian team; the date } \\
\text { corresponds to EB I, and to } \\
\text { Ezero } 13 \text { in particular. }\end{array}$ \\
\hline Dyadovo 10 Floor A & Gak-20465 & Charcoal & $4340 \pm 60$ & $\begin{array}{l}\text { EB I. The published pottery by } \\
\text { the Japanese team has analogy } \\
\text { at Ezero } 13 \text {. But some typical } \\
\text { of the last level ornamentation } \\
\text { motifs are missing in light of } \\
\text { recent limited evidence. }\end{array}$ \\
\hline Dyadovo 10 Floor B & Gak-20466 & Charcoal & $4490 \pm 60$ & \\
\hline Dyadovo 10 Pithos 1 & Gak-20467 & Charcoal & $4530 \pm 120$ & \\
\hline
\end{tabular}

${ }^{\mathrm{a} C}$ Comments: All dates are calibrated with Oxcal 3.5 by Bronk Ramsey (2000). Reference to the original publications of the dates see in Nikolova 1999. References: Nikolova (1999a); Sekime and Kamuro (2000: tables 6 \& 7).

(Nikolova 1999a $\mathrm{a}^{4}$; Sekime and Kamuro 2000). The comments in Table 2 reflect the complexity of the problems that face the stratigraphic analyses of the ${ }^{14} \mathrm{C}$ dates. Figure 2 shows the calibrated values of their individual distribution $(\mathrm{n}=36)$ and the sum-probability that covers the very long period from approximately 3400 to $2550 \mathrm{BC}$ (by $68.2 \%$ probability).

As Figure 2 shows, Bln-5233 preceded all the values from Early Bronze at Yunatsite 15, however, it is close to one date without a clear stratigraphy from Plovdiv-Nebet Tepe, the main site from the Yunatsite culture in the recent Plovdiv region. The Dubene-Sarovka sample indirectly confirms that the Plovdiv-Nebet Tepe ${ }^{14} \mathrm{C}$ date originated from Early Bronze I level. In comparison to the Ezero

\footnotetext{
${ }^{4}$ See in the cited monograph the reference to the original publications of the ${ }^{14} \mathrm{C}$ dates compiled in Table 2 .
} 
culture, Bln-5233 is close to some dates from Ezero 13 (Nikolova 1999a: Table A), as well as from earlier dates from EB Dyadovo (Sekine and Kamuro 2000). In this group of dates, Bln-5233 is noteworthy as it is considered that the genesis of the Yunatsite culture was before $3300 \mathrm{BC}$ (based on comparative stratigraphy and chronology) and possibly confirms the legacy of the disputed dates such as the one from Plovdiv-Nebet Tepe. Of special importance is the fact that the values of the radiocarbon date completely verify the contemporaneous process of genesis of the Early Bronze I cultures in Upper Thrace. It is an objective of further investigation to determine more precise comparative characteristics of the beginning of the different Early Bronze I sites in Upper Thrace. At this time, it can be assumed that the beginning of Dubene-Sarovka IIA had preceded Yunatsite 17 (the earliest Early Bronze documented horizon on the tell).

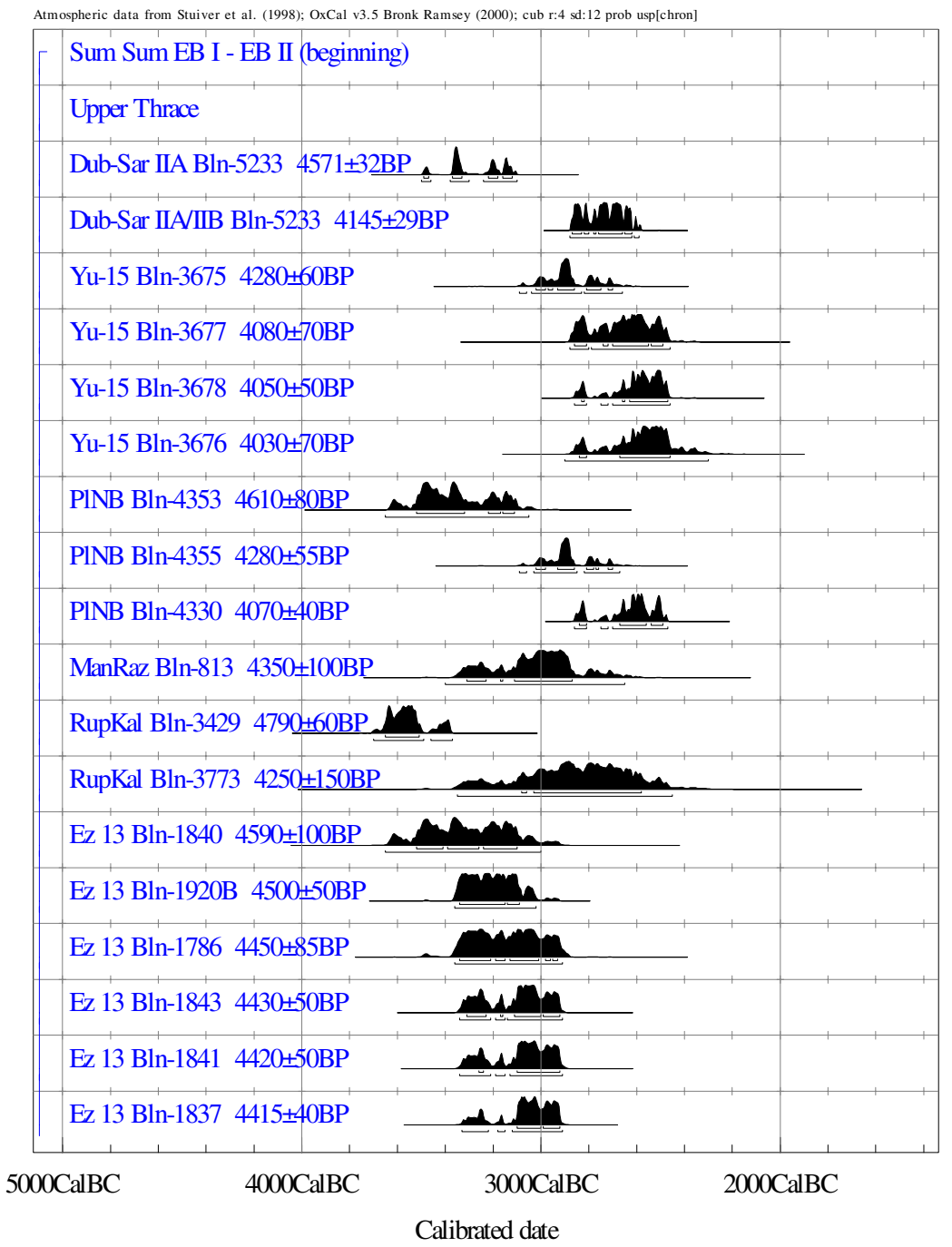

Figure 2A Individual distribution and sum probability of the calibrated ${ }^{14} \mathrm{C}$ dates from Upper Thrace. Early Bronze I to the beginning of Early Bronze II $(n=36)$. Data from Table 2. 


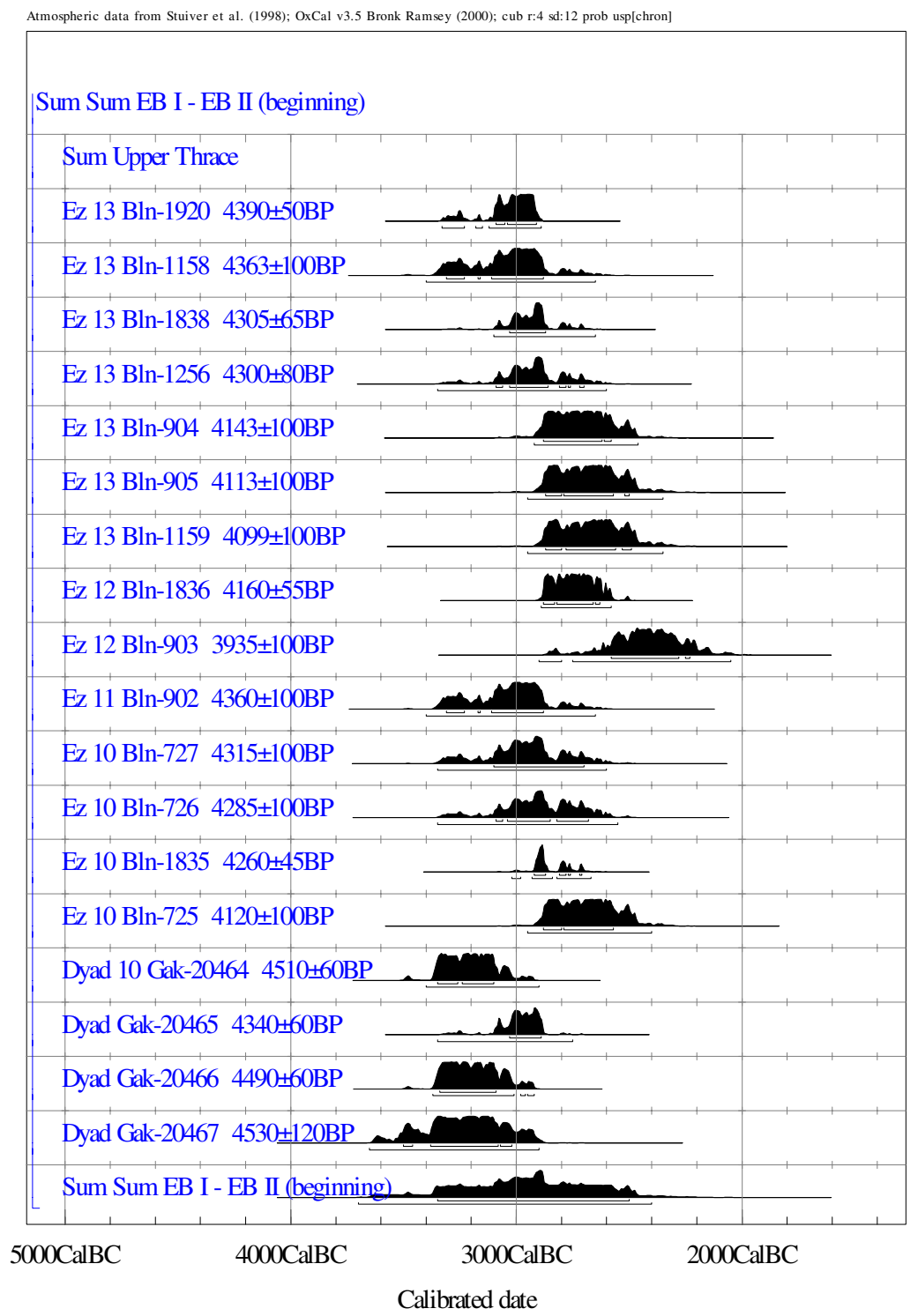

Figure 2B See Figure 2A

The next point concerns the interrelation between the duration of the Early Bronze I sites and the thickness of the cultural layers. The thickness of the stratigraphic levels from Dubene-Sarovka IIA does not exceed $1 \mathrm{~m}$, according to the recent investigation, and is similar to that of Ezero 13-11. In addition, a clear development of the ceramic style is documented at Dubene-Sarovka, which makes it difficult to believe there was an existence of sensitive temporary hiatus during that stage. The accumulation of Early Bronze I on Yunatsite 17-15 is about $1.50 \mathrm{~m}$. It is thicker than Dubene-Sarovka IIA in trench H18-4. The problem requires continued discussion, but for now, the suggestion is that there is a complex interrelation between the different accumulated strata of the prehistoric tells (respectively multilevel settlement); the thickness of those strata cannot be used for any straightforward 
chronological conclusions. The multilevel settlements combine many characteristics not only of the vertical but also of the horizontal stratigraphy and a variety of accumulation processes.

Furthermore, Bln-5231 concerns the beginning of Early Bronze II in Thrace and in the Balkans. Based on recent complex data, it is dated from around $3000 \mathrm{BC}$ (Nikolova 1999a). The calibrated values of Bln-5231 correspond to such chronology that they date the end of level about 2800-2870 BC (as the earliest possible), but stratigraphically and ceramically, level 1 in H18-4 is closer to the end of EB I. Similar problems have posed the other ${ }^{14} \mathrm{C}$ dates from Dubene-Sarovka IIB and especially those from Yunatsite 13 and 11, as well as some of the dates from early Ezero, in particular Ezero 12. Further ${ }^{14} \mathrm{C}$ dates from Upper Thrace will probably better explain the reason for this controversy.

As far as earlier the Early Bronze age in Upper Thrace is concerned, with $68.2 \%$ confidence, the values of the ${ }^{14} \mathrm{C}$ dates in Figure 2 are distributed in the period between 3400 and $2550 \mathrm{BC}$, hence, it covers EB I and the whole EB II (see Nikolova 1999a). That statistical situation corresponds to the peculiarities of many of the individual dates, which have relatively low values. With $95.4 \%$ confidence, the earliest possible chronological border of the beginning of EB I is even $3700 \mathrm{BC}$. But the radiocarbon dates from Early Bronze I are again still not enough for more detailed considerations.

In conclusion, the Dubene-Sarovka excavations have been accomplished as an integrative project for excavation of the prehistoric site, the goal of which has been employing the different opportunities of the archaeological and natural sciences with interrelated and coordinated tasks and levels of investigations. After the terrain achievement of documenting precise stratigraphy and obtaining different kinds of samples from one and the same levels, the results of the integration at the theoretical level of research confirms that the absolute chronology requires complex interactive research.

\section{ACKNOWLEDGMENTS}

We gratefully acknowledge Dr H Erlenkeuser and colleagues (Leibniz-Labor, University of Kiel) for $\delta^{13} \mathrm{C}$ measurements. Thanks are extended to $\mathrm{E}$ Lau and D Teckenburg for assistance in the preparation and measurement of samples in the Berlin Lab (German Institute of Archaeology, EurasianDepartment). Last but not least we thank the two anonymous reviewers for their comments on the manuscript submitted for publication, which helped to improve clarity.

\section{REFERENCES}

Bronk Ramsey C. 1995. Radiocarbon calibration and analysis of stratigraphy: the OxCal program. Radiocarbon 37(2):425-30.

Bronk Ramsey C. 1998. Probability and dating. Radiocarbon 40(1):461-74.

Bronk Ramsey C. 2000. The OxCal Program v.3.5. http: //www.rlaha.ox.ac.uk/orau/06_01.htm.

Görsdorf J. 1990 Die Interpretation von ${ }^{14} \mathrm{C}$-Datierungen im Berliner ${ }^{14} \mathrm{C}$-Labor. Zeitschrift für Archäologie 24: 27-34.

Görsdorf J. 2000 Datierungen im Berliner ${ }^{14} \mathrm{C}$-Labor. Berliner Beiträge zur Archäometrie, Band 17: 12131.

Kovacheva M, Jordanova D, Jordanova J. 1995. Archaeomagnetic study of the Early Bronze settlement Sarovka near Dubene, Karlovo District. Reports of Prehistoric Research Projects 1(1):32-43.
Mook WG, Streurman HJ. 1983. Physical and chemical aspects of radiocarbon dating. Journal of the European Study Group on Physical, Chemical and Mathematical Techniques Applied to Archaeology. PACT 8: 31-55.

Nikolova L. 1999a. The Balkans in later prehistory. British Archaeological Reports, International Series 791. Oxford: British Archaeological Reports.

Nikolova L. 1999b. The Yunatsite culture. Periodization, chronology and synchronization. Reports of Prehistoric Research Projects 2-3, 33-97.

Nikolova L, Görsdorf J. 1998. Stratigraphic sequence and ${ }^{14} \mathrm{C}$-dates from Dubene-Sarovka Tell in the context of the Early Bronze Balkans. Eurasia Antiqua 4: 11-8.

Sekime T, Kamuro H, editors. 2000. Djadovo excavation 1999. A Preliminary Report on the 13th Excavation at 
Dyadovo, Bulgaria. Tokai: Tokai University Thracian Expedition (Dyadovo Studies 3).

Srdoč D, Obelić B, Sliepčević A, Krajcar Bronić I, Hor vatinčić N. 1987 Rudjer Bošković Institute Radiocarbon Measurements X. Radiocarbon 29(1):135-47.

Srdoč D, Obelić B, Horvatinčić N, Krajcar Bronić I,
Sliepčević A. 1989 Rudjer Bošković Institute Radiocarbon Measurements XI. Radiocarbon 31(1):85-98.

Stuiver M, Reimer PJ, Bard E, Beck JW, Burr GS, Hughen KA, Kromer B, McCormac FG, van der Plicht J, Spurk M. 1998. INTCAL98 radiocarbon age calibration, 24,000-0 cal BP. Radiocarbon 40(3):1041-83. 